\title{
Forekomst av skader i russetiden
}

BAKGRUNN Folkehelseinstituttet får hvert år en rekke mediehenvendelser om hvorvidt alkoholinntak blant russen er årsak til skader, og om det er flere skader under russefeiringen. Hensikten med denne studien er å undersøke skadeforekomst i perioden for russefeiringen.

MATERIALE OG METODE Data fra Norsk pasientregister (NPR) er benyttet for å undersøke skadeforekomst hos 16-, 19- og 21 -åringer i årene 2007 til 2011. 19-åringene representerer russen. Skader registrert ved bruk av ICD-10 koder er undersøkt. Mai måned og perioden 20.04-20.05 er sammenliknet med årets øvrige måneder.

RESULTATER 19-åringene har signifikant flere skader i russetiden sammenliknet med 16- og 21 -åringene. I russetiden stod 19-åringene for 41,4\%, 16-åringene for $27,7 \%$ og 21 -åringene for 30,9 \% av skadene. 19-åringene har flere skader i mai måned sammenliknet med de øvrige månedene. Spesielt ses økt forekomst av hodeskader.

FORTOLKNING Det ses en økning i antall skader blant 19-åringer i forbindelse med perioden for russefeiringen sammenlignet med resten av året. Det foreligger ikke data som beskriver årsakene til skadene. Det er behov for bedre registrering av bruk av alkohol eller rusmidler som mulig årsak. Skader behandlet av spesialisthelsetjenesten er trolig av mer alvorlig karakter, og studien kan tyde på at det er en økning i alvorlige skader blant 19-åringer under russefeiringen.

Etter endt videregående skole har man i Norge en russefeiring med sterke tradisjoner og en rekke ritualer. Flere av disse medfører inntak av til dels store mengder alkohol, knyttet blant annet til knuteregler, rebusløp og større russetreff. Det hevdes jevnlig i mediene at feiringen gir økt antall skader, men det foreligger ikke studier der dette er undersøkt.

Den nåværende norske russetradisjonen skriver seg fra 1905 da avslutning av gymnaset med examen artium ble slått sammen med feiring av nasjonaldagen og unionsoppløsningen med Sverige. Men den norske russefeiringen startet lenge før dette og har røtter helt tilbake til 1800-tallet (1). Liknende tradisjoner finnes også $i$ andre land $i$ Norden og Europa, men med annet innhold. I Sverige markeres for eksempel avslutning av skolegang med «Studenten», en feiring som går over én dag og der avgangselevene arrangerer ball eller en festmiddag (2).

Fra ca. 1970-årene har man jevnlig hevdet at den norske russefeiringen er blitt stadig mer utagerende. Det lages årlig medieoppslag om negative konsekvenser av feiringen, som for eksempel: «I alt fikk over 500 russ behandling for skader etter to dager med fyll, vold og festing» (3), «Russefeiringen skader elevenes fremtid» (4) og «140 russ måtte ha legebehandling» (5). Flere av russens knuteregler omhandler inntak av store mengder alkohol som for enkelte kan medføre alvorlige og potensielt dødelige forgiftninger, spesielt vil dette gjelde for kvinner (6).

Folkehelseinstituttet får hver vår en rekke mediehenvendelser angående russefeiring og konsekvenser av rusbruk blant russen. Blix \& Hjellvik har vist at det er økt antibiotikaforbruk blant 19-åringer i mai (7). Ellers har vi ikke funnet noen publiserte studier om russefeiringens helserelaterte konsekvenser, og behovet for mer kunnskap er derfor stort.

Sammenhengen mellom bruk av rusmidler og økt risiko for skade som følge av vold eller ulykker er etter hvert godt dokumentert, spesielt gjelder dette for alkohol (8). Flere studier har vist at alkohol og/eller psykoaktive substanser påvises $\mathrm{i}$ en stor andel prøver fra skadede pasienter innlagt $\mathrm{i}$ akuttmottak $(9,10)$. Det er også publisert metaanalyser som viser at økt alkoholinntak er assosiert med økt risiko for skade (11). Det kan antas at skader som behandles av spesialisthelsetjenesten er skader av en mer alvorlig art. Målet med studien er å undersøke forekomsten av skader behandlet i spesialisthelsetjenesten blant 19-åringer i løpet av russetiden sammenliknet med resten av året, og også sammenlikne med skader blant 16- og 21-åringer for tilsvarende perioder.

\section{Materiale og metode}

I Norsk pasientregister (NPR) er det registrert opplysninger om pasienter som har fătt behandling på sykehus, poliklinikk eller hos avtalespesialist. Det finnes blant annet informasjon om diagnosekoder, og disse kan undersøkes for ulike aldersgrupper. Det finnes ikke informasjon om utdanning, men for å undersøke russekullet har vi tatt ut personer som fyller 19 år det aktuelle året, ettersom det er disse som i hovedsak representerer avgangskullet etter endt videregående skole.

\author{
Linn Engeset Austdal \\ Senter for laboratoriemedisin \\ Sykehuset Østfold \\ Maren Cecilie Strand \\ Vigdis Vindenes \\ Stig Tore Bogstrand \\ stigtore.bogstrand@fhi.no \\ Divisjon for rettsmedisinske fag \\ Nasjonalt folkehelseinstitutt
}

\section{HOVEDBUDSKAP}

Mai måned er den måneden i året 19-åringer har høyest antall skader

19-åringer har signifikant flere skader enn 16- og 21-åringer i perioden russefeiringen pågår

Vi kan ikke fastslå om skadeforekomsten i russefeiringsperioden kan tilskrives bruk av rusmidler, da det ikke foreligger data om skadeårsakene 
Tabell 1 Fordelingen av totalt antall skader i russetiden (20. april - 20. mai) og resten av året for de tre aldersgruppene fordelt på kjønn og totalt for begge kjønn i perioden 2007-11. N = 87233

\begin{tabular}{|c|c|c|c|c|c|c|}
\hline Alder & $\begin{array}{l}\text { Kvinner utenom } \\
\text { russetid (\%) }\end{array}$ & Kvinner russetid (\%) & $\begin{array}{l}\text { Menn utenom } \\
\text { russetid (\%) }\end{array}$ & Menn russetid (\%) & $\begin{array}{l}\text { Totalt begge kjønn } \\
\text { utenom russetid (\%) }\end{array}$ & $\begin{array}{l}\text { Totalt begge kjønn } \\
\text { russetid (\%) }\end{array}$ \\
\hline $16 \stackrel{\mathrm{r}}{\mathrm{n}}$ & $8831 \quad(29,1)$ & $744 \quad(24,6)$ & 16166 & $1444 \quad(29,6)$ & $24997 \quad(31,5)$ & $2188 \quad(27,7)$ \\
\hline $19 a ̊ r$ & $10198 \quad(33,6)$ & $1337 \quad(44,3)$ & $16868 \quad(34,4)$ & $1938 \quad(39,7)$ & $27066 \quad(34,1)$ & $3275 \quad(41,4)$ \\
\hline 21 år & $11288 \quad(37,2)$ & $940 \quad(31,1)$ & $15975 \quad(32,6)$ & $1504 \quad(30,8)$ & $27263 \quad(34,4)$ & $2444 \quad(30,9)$ \\
\hline Totalt & $30317 \quad(100)$ & $3021 \quad(100)$ & $49009 \quad(100)$ & $4886 \quad(100)$ & $79326 \quad(100)$ & $7907 \quad(100)$ \\
\hline
\end{tabular}

Data på antall skader behandlet i spesialisthelsetjenesten for hvert russekull i årene 2007-11 (dvs. personer født 1988-92) er sammenliknet med to grupper bestående av 16- og 21-åringer. Skader for 16- og 21-åringer ble undersøkt fordi dette er ungdom i forholdsvis nær alder og samme livssituasjon som 19-åringene, men samtidig er det lite sannsynlig at de representerer russen.

Vi har sett på data for skader behandlet i sykehus kodet med hoveddiagnose fra kapittel XIX (Skader, forgiftninger og visse andre konsekvenser av ytre årsaker) i ICD-10kodeverket. Materialet ble utlevert anonymisert, med et datasett per skadeepisode som var registrert på de aktuelle årskullene. Alle data for perioden ble slått sammen og analysert, slik at vi ikke fikk vite hvilket år de ulike skadeepisodene hadde skjedd. Dette ble gjort for å sikre anonymitet. Siden materialet ble utlevert anonymisert var det ikke nødvendig med godkjenning fra regional etisk komité.

Russetiden er definert som perioden fra 20. april til 20. mai for enkelte sammenlikninger og statistiske analyser. Mai måned er blitt benyttet der sammenlikning gjøres med resterende måneder. Følgende variabler ble analysert: alder, kjønn, skadetype inndelt etter hovedtilstand fra kapittel XIX i ICD10-kodeverket og måneden skaden fant sted.

\section{Statistisk analyse av data}

Khikvadrattest ble benyttet for å undersøke om det var statistisk forskjell i antall skader $i$ de tre aldersgruppene $i$ perioden definert som russetiden (Bonferroni-korreksjon ble ikke vurdert som aktuelt grunnet enkel khikvadrattest av kjønnsforskjeller). Alle analyser ble gjort ved hjelp av IBM SPSS Statistics versjon 20 . P-verdier $<0,05$ ble definert som statistisk signifikant.

\section{Resultater}

I perioden 2007-11 ble det totalt registrert 87233 skader utelukkende i sykehus for de tre aldersgruppene. Menn sto for 53895 $(62 \%)$ av disse oppholdene og kvinner for 33338 (38\%). 16-åringer sto for 27185
(31\%) av disse skadene, 19-åringene for $30341(35 \%)$ av disse og 21-åringene for 29707 (34\%).

I russetiden har 19-åringene høyere prosentvis andel av totalt antall skader $(41,4 \%)$ enn for resten av året $(34,1 \%)$. Når alle skadene fordeles dikotomt på kjønn, ser vi at 19 år gamle menn utgjør 39,7 \% av skadene i russetiden og 19 år gamle kvinner står for $44,3 \%$ av skadene i russetiden (tab 1 ).

Totalt sett ses signifikant flere skader blant 19-åringene $(p<0,01)$ i perioden 20 . april til 20. mai enn blant både 16- og 21-åringer (fig 1). 19-åringene har høyere totalt antall skader i mai måned enn i de andre månedene, i tillegg til at de også har flere skader enn de to andre aldersgruppene i denne måneden (fig 2).

For begge kjønn og alle aldersgrupper var forekomsten av skader høyest i de tre diagnosegruppene S60-S69 (skader i håndledd og hånd), S90-S99 (skader i ankel og fot) og S00-S09 (hodeskader).

I mai var de vanligste diagnosegruppene for 19-åringene S90-S99 (skader i ankel og fot) $(21,4 \%)$, S60-S69 (skader i håndledd og hånd) $(20,6 \%)$ og $\mathrm{S} 00-\mathrm{S} 09$ (hodeskader) $(19,7 \%)$.

Antall ekstremitetsskader (S40-S99) blant 19-åringer er høyere i mai enn i de øvrige månedene (fig 3). Det høyeste antallet ekstremitetsskader i mai finner man imidlertid blant 21-åringene. Her ses ingen økning sammenliknet med tidligere måneder, men det ses et betydelig fall i juni, juli og august.

Det er flere hodeskader i mai måned blant 19-åringene enn blant de to andre aldersgruppene, og det er også høyere antall hodeskader i mai for 19-åringene enn de andre månedene i året (fig 3).

Antall intoksikasjoner (ICD-10: t4n, t50 og t51) i mai er høyest blant 19-åringene

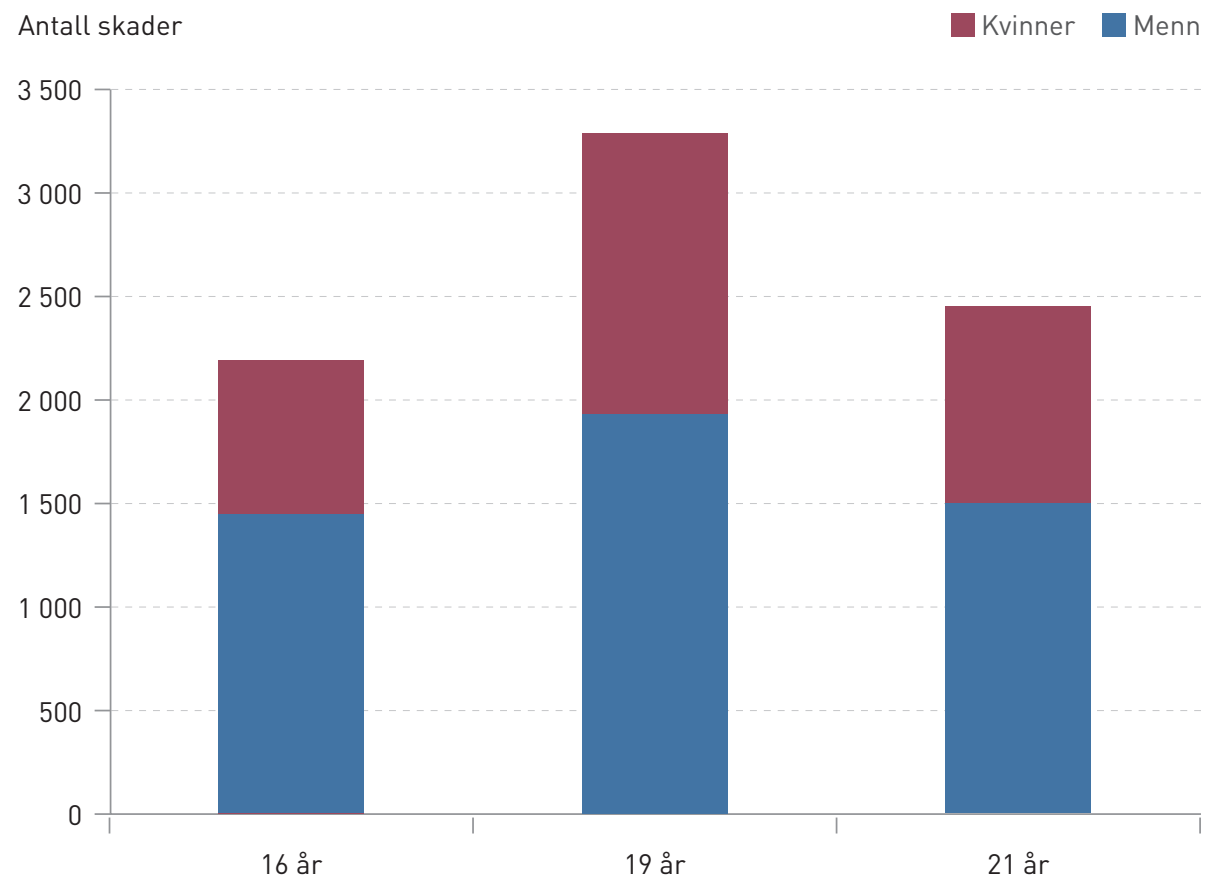

Figur 1 Totalt antall skader i russetiden (20.april-20.mai) og kjønnsfordelingen for de tre aldersgruppene i perioden 2007-11. N = 7907 


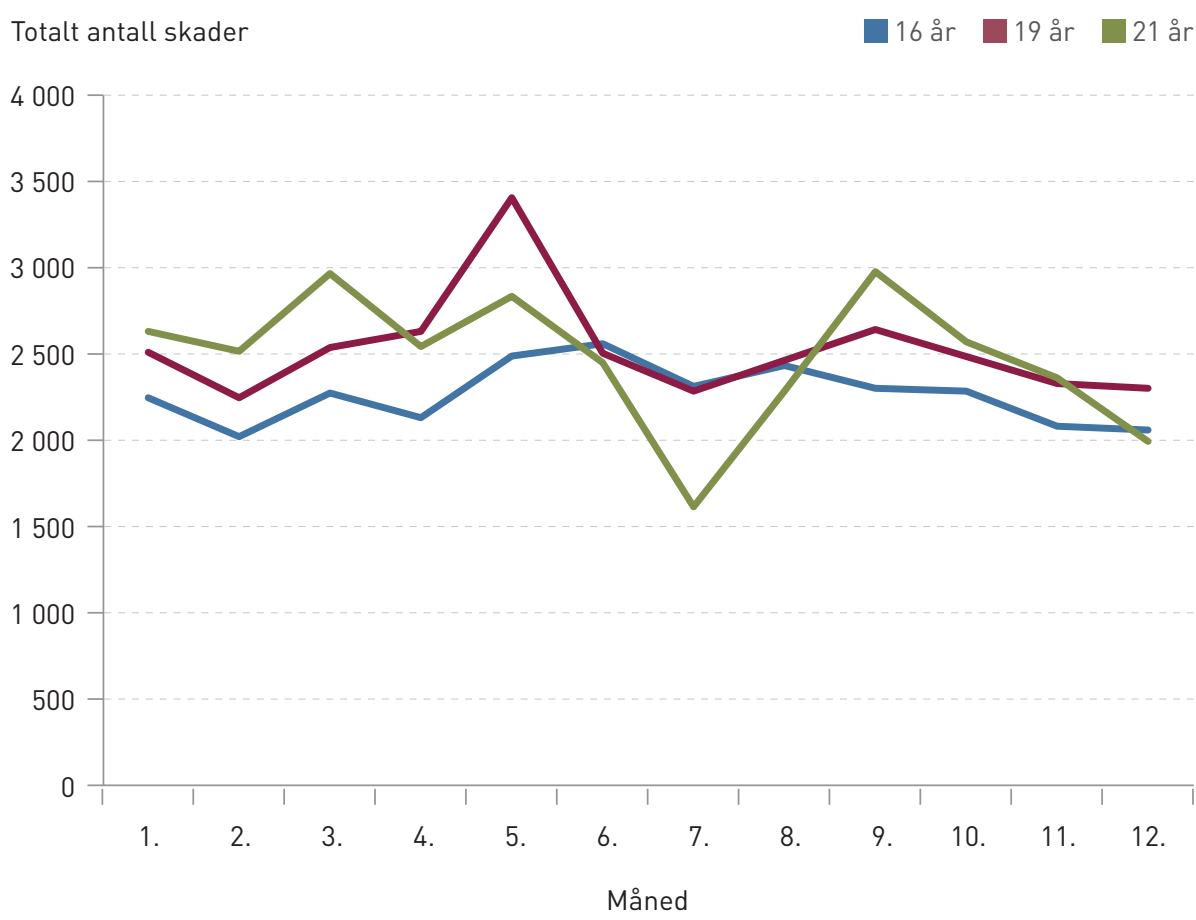

Figur 2 Månedsfordelingen for totalt antall skader fra kapittel XIX fra ICD-10-kodeverket (Skader, forgiftninger og visse andre konsekvenser av ytre årsaker) for de tre aldersgruppene i perioden 2007-11. N = 87233

sammenliknet med de to andre aldersgruppene, men forskjellen fra 16-åringene er liten. De to yngste aldersgruppene har høyere intoksikasjonstall enn 21-åringene for alle årets måneder. For 19-åringene var antall alkoholintoksikasjoner (t51) høyest i mai måned og høyere enn for 16- og 21-åringene, men antall registrerte alkoholintoksikasjoner var uansett ikke veldig høyt.

Menn skader seg mer enn kvinner, dette gjelder for alle skadetyper. For intoksikasjoner (T4n-T65) er imidlertid forekomsten høyere blant kvinner enn menn i alle de tre aldersgruppene.

\section{Diskusjon}

Denne studien viser at 19-åringene har økt forekomst av skader i perioden som russefeiringen pågår, sammenliknet med øvrige måneder. Spesielt ses en betydelig økning i antall hodeskader. Denne økte forekomsten av skader ses ikke blant 16- eller 21-åringene. Vi anser det som sannsynlig at funnet har sammenheng med russefeiringen.

Som for resten av året, skader menn seg hyppigere enn kvinner også i russetiden, selv om den prosentvise fordelingen av antall skader mellom kjønnene viste mindre forskjeller for 19-åringene i russetiden. Det er kun for intoksikasjoner at kvinner totalt sett har en betydelig høyere forekomst enn menn. En mulig årsak til dette er at kvinner får høyere promille enn menn ved samme alkoholinntak, og at risiko for intoksikasjon øker. For menn var forekomsten høyest blant skader i håndledd og hånd, ankel og fot samt hodeskader. Selv om kvinner også hadde høy forekomst av disse skadene, kan en mulig forklaring på forskjellene i det totale antallet skyldes mer risikofylt atferd blant menn enn kvinner.

Blant skadede og forulykkede er det tidligere vist at forekomsten av alkohol- og rusmiddelbruk er høy $(9,11,12)$. Hvor mye av økningen i skader som kan tilskrives bruk av alkohol og/eller rusmidler alene, er ikke mulig å fastslå på bakgrunn av våre data, da årsakskoder og dermed registrering av rusmiddelbruk er svært mangelfull i pasientregisteret. Bogstrand og medarbeidere har undersøkt forekomst av rusmidler og andre psykoaktive stoffer blant pasienter innlagt i akuttmottaket ved Oslo universitetssykehus, Ullevål (12). De viste at over $40 \%$ av pasientene som ble innlagt på grunn av skader, hadde inntatt alkohol eller andre rusgivende stoffer. Forekomsten var spesielt høy hos yngre pasienter ( $<35$ år), og spesielt yngre menn, der det ble påvist ett eller flere rusgivende stoffer hos mer enn halvparten av pasientene. Det vanligste stoffet var likevel alkohol alene.

Data fra Norsk pasientregister vil være godt egnet til å undersøke forekomst av alvorlige skader, og det bør informeres om konsekvenser av slike skader i den aktuelle gruppen. Opplysninger fra pasientregisteret avdekket at det er mangelfull registrering av årsakskoder i forbindelse med skadebehandling ved sykehusene. Muligheten til å benytte opplysninger fra slike registre til å finne årsaker til ulike hendelser/tilstander er derfor ikke mulig. Det er imidlertid viktig å kjenne til forekomsten av skader i forbindelse med russefeiringen sammenliknet med øvrige måneder, og det er behov for bedre registrering av sammenhenger. Dette er viktig med tanke på forebyggende arbeid for å forhindre alvorlige skader hos unge mennesker. Det er i flere utenlandske studier vist at pasienter innlagt på sykehus ønsker alkoholintervensjon og at denne har gunstig effekt $(13,14)$. En rusrelatert innleggelse vil være en mulighet til å motivere pasienten til å redusere rusbruken. Spesielt unge vil kunne ha nytte av dette.

Dataene benyttet i denne studien avdekker kun skader behandlet i spesialisthelsetjenesten for de tre aldersgruppene. Dersom studien også hadde innebefattet skader behandlet i primærhelsetjenesten, kunne dette vist andre årstidsvariasjoner og forskjeller mellom de tre aldergruppene. Man kan tenke seg at skader behandlet av spesialisthelsetjenesten i utgangspunktet er skader av mer alvorlig karakter, slik at resultatet fra denne studien viser at 19-åringene har en økning i antall alvorlige skader i perioden russefeiringen finner sted sammenliknet med de to andre aldersgruppene.

En svakhet ved studien er at det ikke finnes data som gjør det mulig å skille russ fra andre 19-åringer. Vi har derfor undersøkt skadeforekomsten blant alle 19-åringer. Over $90 \%$ av alle 16-åringer starter på videregående utdanning, men kun halvparten fullfører denne utdanningen på tre år (7). Våre data vil derfor inneholde en del personer som ikke var russ, selv om de fylte 19 år de aktuelle årene, mens andre var russ $i$ andre aldersgrupper. Blant russen vil vi finne en del individer som fylte 20 år det året de deltok i russefeiringen. Disse dekkes ikke av vårt materiale. Det virkelige skadetallet for russ i russetiden kan dermed være høyere eller lavere enn det vi har basert våre beregninger på.

\section{Konklusjon}

Denne studien viser at det er økt forekomst av skader blant 19-åringer i tiden da russefeiringen pågår. Skader behandlet av spesialisthelsetjenesten kan være skader av mer alvorlig karakter. Resultatet fra denne studien viser dermed at 19-åringene har en økning i antall alvorlige skader i perioden russefeiringen finner sted sammenliknet med de to andre aldersgruppene.

Norsk forskning tar i økende grad i bruk helseregistre for å kunne fremskaffe viktig kunnskap om helse, årsaksforhold, behandlingsresultater etc., og det er viktig at det etableres en bedre praksis i helsevesenet for å fastsette diagnosekoder og årsakskoder. På den måten vil man få tilgang på data som ikke lar seg undersøke på andre måter. 

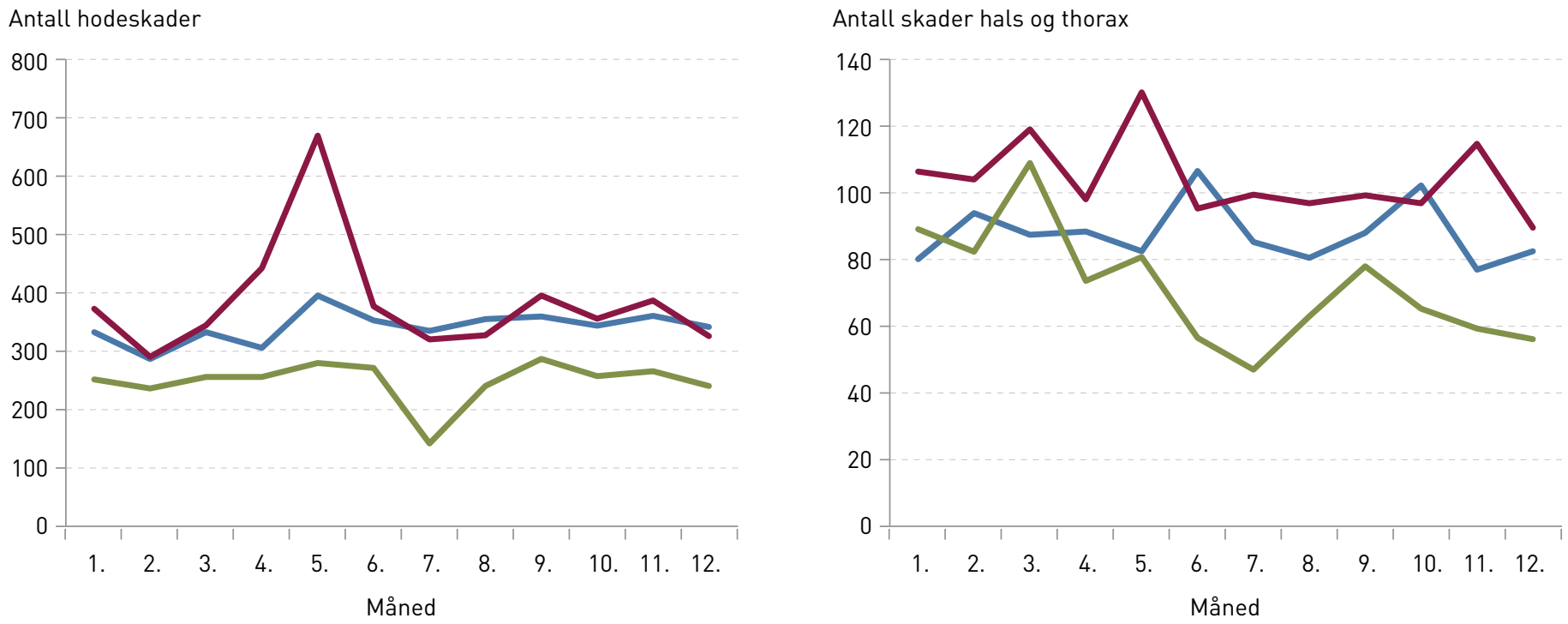

Antall skader i buk, rygg og columna
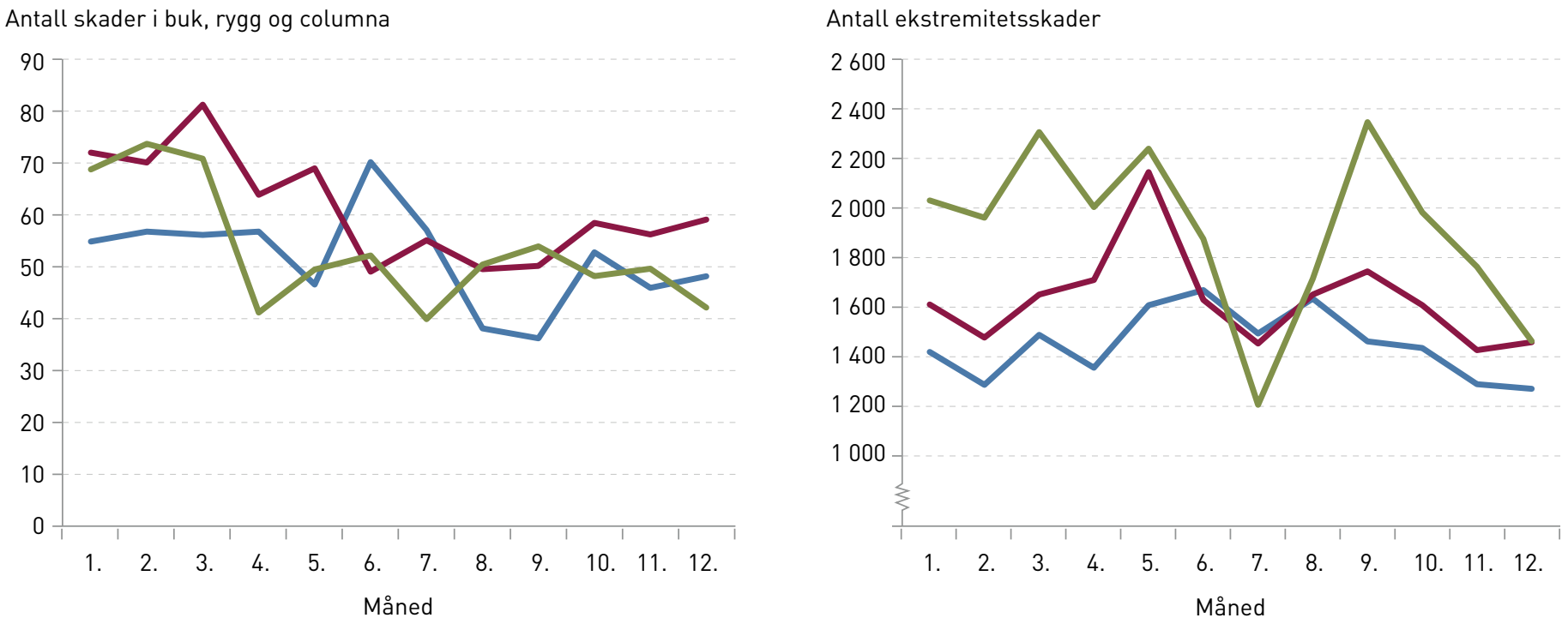

Antall intoksikasjoner

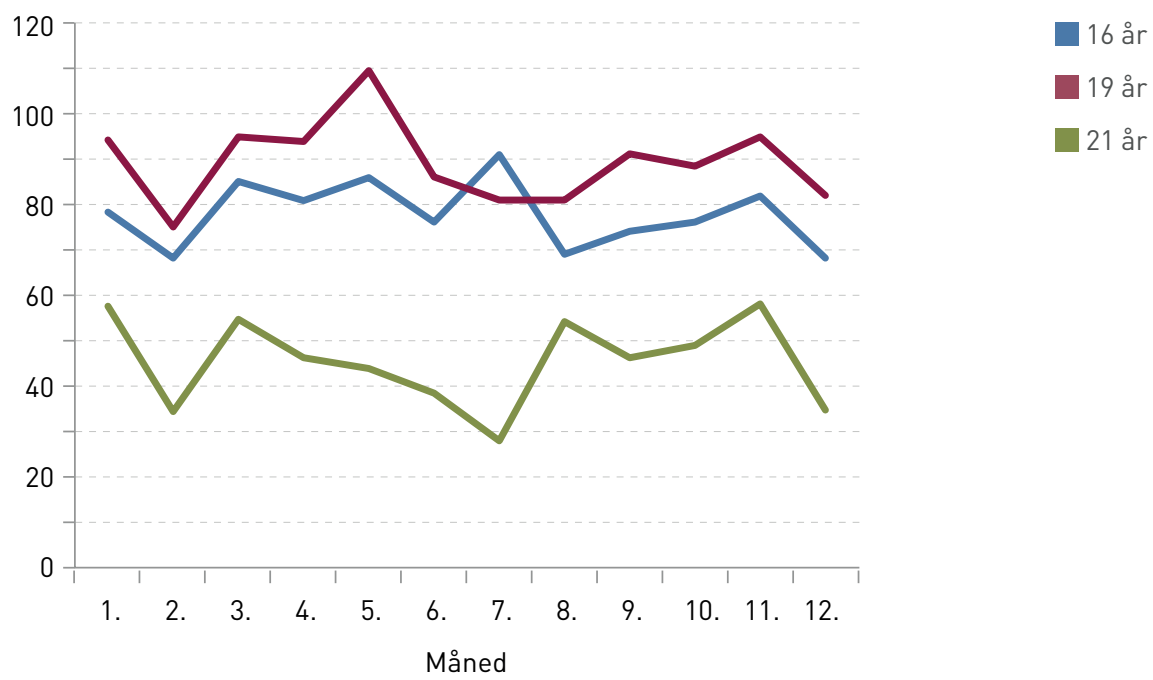

Figur 3 viser oversikt over månedsfordelingen i antall skader for forskjellige diagnosegrupper for de tre aldersgruppene i perioden 2007-11. N = 87 233 


\section{Linn Engeset Austdal (f. 1979)}

er lege i spesialisering i medisinsk biokjemi. Forfatter har fylt ut ICMJE-skjemaet og oppgir ingen interessekonflikter.

\section{Maren Cecilie Strand (f. 1979)}

er spesialist i klinisk farmakologi og overlege. Forfatter har fylt ut ICMJE-skjemaet og oppgir ingen interessekonflikter.

\section{Vigdis Vindenes (f. 1974)}

er ph.d., spesialist i klinisk farmakologi og avdelingsdirektør.

Forfatter har fylt ut ICMJE-skjemaet og oppgir ingen interessekonflikter.

Stig Tore Bogstrand (f. 1979)

er ph.d., sykepleier, postdoktor og førsteamanuensis II.

Forfatter har fylt ut ICMJE-skjemaet og oppgir ingen interessekonflikter.

\section{Litteratur}

1. Bråthen TV. Om meningen med rusgiftbruk sett gjennom russefeiring som et rituale. Forbundet Mot Rusgift. www.webcitation.org/6EOfpy $4 z$ (1.9.2014).

2. Studeravidare Sverige. Studenten 2013 www.webcitation.org/6EOgfChjB (1.9.2014)

3. Gudbrandsdølen Dagningen. Russ uten grenser. www.webcitation.org/6E0h3x7L5 (1.9.2014).

4. Holm AK. Russefeiringen skader elevenes fremtid. VG 27.3.2007. www.webcitation.org/6EOhMvsXg (1.9.2014)

5. Kvilesjø SO. 140 russ måtte ha legebehandling. Aftenposten 29.4.2012. www.webcitation.org/ 6EOhTXuCE (1.9.2014).

6. Nasjonalt folkehelseinstitutt. Russ og rus. www.webcitation.org/6EOfyFQkE (1.9.2014).

7. Blix HS, Hjellvik V. Økt bruk av antibiotika blant 19-åringer i mai. Tidsskr Nor Lægeforen 2012; 132: $1084-8$

8. Cherpitel CJ, Ye Y, Bond J. Alcohol and injury: multi-level analysis from the emergency room collaborative alcohol analysis project (ERCAAP). Alcohol Alcohol 2004: 39: 552-8.

9. Cherpitel CJ. Alcohol and injuries: a review of international emergency room studies since 1995 Drug Alcohol Rev 2007; 26: 201 -14

10. Vitale $S$, van de Mheen D. Illicit drug use and injuries: A review of emergency room studies. Drug Alcohol Depend 2006; 82: 1-9

11. Taylor B, Irving HM, Kanteres F et al. The more you drink, the harder you fall: a systematic review and meta-analysis of how acute alcohol consumption and injury or collision risk increase together. Drug Alcohol Depend 2010; 110: 108-16

12. Bogstrand ST, Normann PT, Rossow I et al. Prevalence of alcohol and other substances of abuse among injured patients in a Norwegian emergency department. Drug Alcohol Depend 2011; 117: $132-8$.

13. The impact of screening, brief intervention and referral for treatment in emergency department patients' alcohol use: a 3-, 6- and 12-month follow-up. Alcohol Alcohol 2010; 45: 514-9.

14. Broyles LM, Rosenberger E, Hanusa BH et al. Hos pitalized patients' acceptability of nurse-delivered screening, brief intervention, and referral to treatment. Alcohol Clin Exp Res 2012; 36: 725-31. 